\title{
Is Connie a New Woman on the Way to Happiness?-An Analysis of Connie in Lady Chatterley's Lover from the Perspective of Feminism
}

\author{
Ting Wen \\ College of Foreign Studies, Nanjing Agricultural University, Nanjing, China
}

\begin{abstract}
Lady Chatterley's Love, the last novel written by David Herbert Lawrence, caused quite a series of controversy in the circle of literary critic and among the readers. The heroine in the novel, Connie, Lady Chatterley, is a key figure to be considered when we interpret this work thoroughly. Connie is still regarded as a brave woman at that time that defies the shackles of old ethics and seeks personal emancipation. Can Connie be counted as a real new woman? Why? This paper attempts to answer this question from the perspective of feminism.
\end{abstract}

Index Terms - Lady Chatterley, a new woman, feminism

\section{INTRODUCTION TO D. H. LAWRENCE AND THE WORK}

David Herbert Lawrence (usually written as D. H. Lawrence) was born in Nottinghamshire, UK in 1885 whose father was a coal miner and whose mother was from a middle-class family. Because of this status difference between them, his parents had a very bad relationship which had a profound effect on his later works. In the 20th century, Lawrence was one of the most important and controversial writers in English literature. His major achievements included novels, poetry, drama, prose, travel notes and letters. In 1930, Lawrence passed away in Munce, France. With regard to Lawrence's works, most of them are too erotic that have been savagely attacked and criticized by the critic. However, he has made great efforts to explore the depths of human soul in his works and has successfully used the impressive artistic description, so his works have been attached importance by the world literary circle from his lifetime to the present. Few novelists of the present age, like Lawrence, have been so cruelly abused by the world; At the same time, it is rare for a modern English writer to find a man like Lawrence who is adored by the elite young intellectual class as well.

D. H. Lawrence's Lady Chatterley's Lover was widely regarded as a controversial novel which was published in the year of 1928 in Italy at first. However its edition did not come out in public in the United Kingdom until 1960. At that point, this book became notorious instantly for its daring explicit description which stirred extreme controversy in literary circle and readers. The main plot of this novel is as follows. In 1917, Clifford Chatterley, a central English miner and noble landowner, married Connie, hurried on his honeymoon, and returned to the army instantly. He was later sent home with paralysis below his waist, only to act in a wheelchair. After his father died, Clifford inherited the estate and the title, becoming a wealthy owner. While his wife Connie was a lively, open-minded girl, full of energy and good health, who had been educated freely from an early age. She took great care of her incapacitated husband and assisted him in writing novels. Although Clifford remained aristocratic in appearance, his energy was dwindling and his feelings were fading because of the loss of sexual function which his wife Connie could not bear any longer. Connie met Oliver Mellors by chance, a retired soldier as a new caretaker in the Clifford's garden, in the woodshed, and fell in love with him at first sight. Connie used to sneak into the cottage to enjoy the sex life of lust, passion, and primal joy with Mellors, giving Connie a renewed desire to live. Soon, Connie was pregnant unexpectedly, and all of sudden Mellors's wife showed up and made their secret affair known in public. In the end, Connie made up her mind to divorce with Clifford, and Mellors would be reunited with Connie after receiving a divorce certificate from his wife. Liu Cong (2013) analyzed that Lawrence shows a clear consciousness of female emancipation by means of describing the eulogy of free love in Lady Chatterley's Lover. However, Lady Chatterley's Lover was of significance to a certain extent, definitely portraying a new image of women striving for their own existence and happiness, like Lady Chatterley, Connie, in the text. Then, whether Connie can be counted as a new woman will be further analyzed from the perspective of feminism in this thesis.

\section{INTRODUCTION TO FEMINISM}

Feminism, also known as women's emancipation and gender equality, refers to ending sexism, sexual exploitation, 
sex discrimination and sexual oppression. The social theory and political movement created and launched to promote gender equality also focuses on the analysis of gender inequality and the promotion of rights, interests and issues at the bottom of the sexual hierarchy, in addition to criticism. At the end of the 19th century, the first wave of women's liberation movement was at issue, with the demand for gender equality, including in the life course of men and women, In other words, equality between the sexes requires civil and political rights, opposition to aristocratic privileges and polygamy, emphasizing that there is no difference in intelligence or ability between men and women. The most important goal is to strive for the equivalence of family labour and social labour and the equivalence of political rights, often referred to as the "feminist movement". The second wave of feminism began in the 1960s and 1970s. It is believed that the Second Women's Liberation Movement originated in the United States. The second wave of the women's movement (also known as the New Women's Movement) focused on achieving full social and economic equality, measures on equal payment for men and women, legalization of abortion, freedom of homosexuality, the establishment of divorce laws, nurseries, rape protection stations, etc., and on various levels. The keynote was to emphasize the division of labour between the two sexes and to eliminate the unequal pay for equal work between men and women which requires eliminating gender differences as the basis for women's subordination to men in social relations between the sexes and meeting for sub-areas to be open to the public accordingly, etc. However, the third wave of feminism movement happened in the mid-1990s that was launched by the Generation X-ers who were born during the 1960s and 1970s in the developed world. Even though these persons got benefitted profoundly from the legal rights which had been already realized successfully by the first and second-wave feminists, at the same time they critiqued the unfinished work of second-wave feminism.

The aim of feminism theory is to understand the essence of inequality and to focus on gender politics, power relations and sexuality. Feminist political action challenges issues such as reproductive rights, the right to abortion, the right to education, domestic violence, and maternity leave for pregnant women, equal pay, voting rights, sexual harassment, gender discrimination and sexual violence. The themes of feminist inquiry include discrimination, stereotype, reification (especially about sex), body, household distribution, oppression and patriarchy. Here are some suggested methods provided according to the theory of feminism which are studying how women are portrayed in literary works, and critiquing sex discrimination, reconsidering literary works by male and female authors, critiquing the male superiority, and showing sympathy for female's tragic fate, exploring the feminist consciousness embodied in literary works, advocating equality between men and women and rewriting literary history.

\section{AnAlysis of Whether ConNie Is A New Woman on the Way to Happiness}

\section{A. From the Plot of This Work}

From structure of the title (Lady Chatterley's Lover), clearly, the protagonist is Lady Chatterley's lover, Oliver Mellors, a male character. Just as Simone de Beauvoir (1972) said in The Second Sex: "What is a woman? How is she constructed differently from a man? She is constructed by a man." It was connected with the present social phenomena, showing that women were defined and interpreted by men as subordinate, secondary or even nonexistent players to men in the major social institutions. On the contrary, Lawrence set a female character as a protagonist in this text. Looking back on the plot can help readers figure out that it is Lady Chatterley, Connie, who marries Clifford paralyzed and impotent back from the war, has an unsatisfied affair with Michaelis, hires a caring nurse, Mrs. Bolton, to tender Clifford, has a satisfying affair with Mellors, goes away to Venice for a vacation, which is the turning point of the story, admits to Clifford her pregnancy with Mellors and begs an instant divorce with Clifford. Eventually, what Connie will do is to keep waiting for Clifford's divorce, baby's coming or happy life with Mellors, which is an open ending of the story. Therefore, it can be inferred that Connie as a female character is the puller of the whole story and her presence promotes the process of the plot, presenting Connie's active role in Lady Chatterley's Lover. In addition to this, it is obvious to discover the initiative and existence of women as Anna's daughter, Ursula in Lawrence's Rainbow, Mrs. Morel in Sons and Lovers as well as his other works.

In Lady Chatterley's Lover, male and female characters hold a consistently traditional attitude towards women. Here are different attitudes extracted from the novel: To women by the intellectuals gathering in Clifford's study:" 'It's hopeless. I just simply can't vibrate in unison with a woman. There is no woman I can really want... My God, no! I'll remain as I am, and lead the mental life.' "; (Lawrence, 2008, P.52-53) To women by Mrs. Bolton: “'When I look at women who're never been warmed through by men, well, they seem to me poor dolls after all, no matter how they may dress up and gad" "; (Lawrence, 2008, P.219) To Mrs. Bolton by Clifford: "With Clifford, she was shy, almost frightened and silent. He liked that, and soon recovered his self-possessions, letting her do things for him without even noticing her. 'She is a useful nonentity!' said Clifford"; (Lawrence, 2008, P.108) Accordingly, Clifford together with several male characters shows contempt to women, regarding them as silent, boring, lifeless and dependent nonentity, illustrating stereotypical and distorted images of women. As James Tompkins said in his article, "Me and My Shadow", depicting what people thought of female: "Women are used as extensions of men, mirrors of men, devices for showing men off, devices for helping me get what they want. They are never there in their own right, or rarely. Sometimes I think the world contains no woman." (James Tompkins, 1987, P.169-178) which reflects women just play roles of the other, the second to men. Nevertheless, what surprises readers is the attitude to women by female characters. The male characters in the work suppose that women are destined to be attached to men in their inner mind. Without men, women cannot be 
called real individuals, just dead dolls. Such thinking determines their choices in their own life. Only when they feel they have men to lean on, can they feel they exist as human beings regardless of despise or dislike from the men. They also tend to criticize women who are different from them and who attempt to break these images of women built traditionally by the world.

Apart from the stereotypical attitudes presented above, there is also a distinct attitude towards women held by Mr. Winter and Mellors. To Connie by Mr. Winter: "After all, Mr. Winter, who was really a gentleman and a man of the world, treated her as a person and a discriminating individual. He did not lump her together with all the rest of his female womanhood in his 'thee' and 'tha' "; (Lawrence, 2008, P.171) To Connie by Mellors: “ 'Thank God I've got a woman who is with me, and tender and aware of me. Thank God, she is no bully, nor fool. Thank God she is a tender, aware woman." " (Lawrence, 2008, P.370) Mr. Winter, unlike other male characters, considers Connie as a woman who deserves to share the same identity with men as a person and a discriminating individual. Then Mellors treats Connie as an independent woman and does not pay much attention to the status of Connie. As a matter of fact, Connie is a pure-hearted, real woman in the eyes of Mellors who is attracted by Connie's charming look and adorable personality. Hence, Mr. Winter and Mellors show admire and positive attitudes toward Connie, appreciating this new image of women.

What's more, Connie says to Mellors: "I don't care what they think. I do! I don't want them to handle me with their unpleasant cold minds, nor while I'm still at Wragby. They can think what they like when I'm finally gone." (Lawrence, 2008, P.298) Connie is described as a healthy, independent, pure, compassionate woman with a natural passion for freedom and happiness. While Mellors is a servant, a gamekeeper of her husband, he has no status, no wealth but only his own possession. Under such circumstance, Connie is willing to give up everything to be with Mellors, such as the honorable title, the abundance of life. Although they are facing a huge gap in class, they confront the same situation and fate at that moment. Their relationship is based on the equal love and common responsibility between them as a man and woman, which motivates Connie to choose Mellors, casting everything into the winds.

Connie also ponders the relationship between Clifford and herself, "There was nothing between them. She never even touched him nowadays, and he never touched her...he tortured her with his declaration of idolatry. It was the cruelty of utter impotence. And she felt her reason would go way, or she would die." (Lawrence, 2008, P.149) Clifford returns from the war, paralyzed from the waist down, impotent. He fills the home with gloomy, misshapen atmosphere of marital life that possesses the image of most English aristocrats, mechanical, conservative, dreary, and unfeeling to women. His presence is like the gloomy city called Wragby where they live that Connie can't stand any longer. Then, the female character Connie challenges the unfair fate, unhappy and unsound marital life courageously, says no to Clifford and Clifford's nothingness, and asks for an immediate divorce with Clifford to pursue the rights and happiness that are supposed to belong to her, from the view point of the plot in the work who shows up as is a new image of woman at that moment. Here comes a vital question, can Connie be called a real new woman?

\section{B. From the Plot of This Work from the Theory of Feminism}

As a matter of fact, the term "New Woman" was coined by a writer and public speaker called Sarah Grand. Sarah Grand (1894) explained this new phrase: "The New Woman, a significant cultural icon of the end of the century, departed from the stereotypical Victorian woman. She was intelligent, educated, emancipated, independent and self-supporting. The New woman was not only middle-class female radicals, but also factory and office worker.'(P.271) The Definition of "new woman" also explained from Merriam Websteris "a woman especially of the late 19th century actively resisting traditional controls and seeking to fill a complete role in the world as a man." During that time, the women challenged the conventional gender roles, meanwhile, suffered from hostility from men and women who objected to women's public presence which is vividly presented in Connie from the work.

An American feminist, Kate Milllett (1977), said in her Sex Politics: "The frigid woman of Victorian period was withholding assent, the 'new women', could, if correctly dominated, be mastered in bed as everywhere else." According to her, Connie was such a "new woman" that the frigid woman of Victorian period didn't agree with, for she relinquished her "self, ego, and individuality-things woman had but recently developed..." We can also see that in Kate Millet's eyes, the relationship between Connie and Mellors was still the male-dominated one, Connie still didn't get rid of the embarrassing situation of "second sex". Furthermore, Lawrence's novel, completed in the nineteen twenties, was intended to criticize the rigidity and incompetence of human organism caused by industrial civilization, as well as discord between human beings and the natural world to seek a relationship that will enable the two sexes of human beings, mankind and the natural world to live in harmony with each other. D. H. Lawrence believed that the harmonious relationship between the sexes was the attainment of harmony between man and nature. It is obvious that Mellors was Lawrence's ideal male incarnation, and he had passed through a woman like Connie. Connie behaved as an ideal woman, who was gentle, submissive, and willing to dedicate herself to a man like Mellors. When getting to know the character Connie, one cannot help thinking of what proposed by an Austrian neurologist and the founder of psychoanalysis, Sigmund Freud, who put forward the personality structure, making up of three components "id, ego and super-ego". As Freud (1933) presented the relationship among these three components of human's personality structure that the id is associated with the trends that are uncoordinated instinctual set. However, the super-ego plays a critical and moralizing part in people's daily life. The ego is an organized, realistic part which has a role of balancing the desires between the id and the super-ego in people's inner heart. With regard to this theory, Connie was on the way to 
pursue her ego, while all morality and dogma became the imprisonment of her soul in a dying environment. Under such circumstance, Freud's theory had little effect on Connie, and she returned to the most primitive human condition, beginning sex with Mellors' body, feeling the comfort of the soul gradually, generating love with Mellors slowly. Therefore, Connie was so brave that she gave up everything she owned for the liberation of her soul. As time goes by, they were in a state of happiness, and every word they promised as well as every comfort between them, seemed to be breaking the chains of the age, and making Connie liberate freely, giving Connie the fullness of her soul's wings. It was Mellors, a seemingly humble soul, that made Connie experience the love of the world, and gave her courage and strength to fight with the earthly world dauntlessly. Thus, Mellors symbolizes the spirit of feminism and provides the motivation of women's emancipation in that era.

But can we not help asking whether the relationship between Connie and Mellors can last harmoniously and permanently? If there is one day Mellors lost his passion for Connie, or Connie was no longer gentle and submissive, and their relationship would remain lasting? Lawrence himself did not seem sure of their relationship, and I thought this was what Lawrence left at the end of the novel. That is to say, Connie can't be called a real new woman certainly.

More Examples further cited in the text are as follows: "She had been supposed to have rather a good figure, but now she was out of fashion: a little too female, not enough like an adolescent boy. Disappointed of its real womanhood, it had not succeeded in becoming boyish and unsubstantial and transparent; instead it had gone opaque. Somehow they too were going flat, slack and meaningless." (Lawrence, 2008, P.92-93) That's what she mutters to herself with her body naked in front of the mirror, after she meets Mellors in the woods by accident. She resents being too feminine in her body which she regards as a meaningless figure, eager to have the same unsubstantial and transparent figure as an adolescent boy. Therefore, her doubt about her own female body and admiration for the male body shows that Connie does not fit with the qualities of new woman actually.

"Her tormented modern-woman's brain still had no rest. Was it real? And she knew, if she gave herself to the man, it was real. But if she kept herself for herself it was nothing." (Lawrence, 2008, P.155) From the above quoted sentences, it is an apparent manifestation of the lack of independence of Connie's mind and body, which doesn't conform to the characteristics of new women. Connie asks Mellors: “ 'Do you want me? Quite! And when do you want me? But you trust me, don't you? But you want me, don't you? We will live together and make a life together, won't you? You'll keep the tenderness for me, won't you?"” (Lawrence, 2008, P.443) Upon hearing her questions, Mellors answers, "“I love thee that I can go into thee. It heals it all up, that I can go into thee. I love thee that tha opened to me. I love thee that I came into like that.' " (Lawrence, 2008, P.443) With Connie's constant questions to Mellors considered, it is clear that she is less confident in the relationship between them. Mellors then replies that he loves her just for his own sexual needs, because Connie could submit to him and satisfy his sexual demands in the way he wants without taking their relationship as independent subjects into serious consideration. Thus we can conclude she isn't really a "new woman" that should be "independent" physically and mentally.

\section{CONCLUSION}

In the last part of Lady Chatterley's Lover, Connie and Mellors escaped from Chatterley's manor, but in reality, she fled from not only her husband's control but also the worldly imprisonment. By describing the women who were oppressed in that era and were enslaved by feudal morality, the writers managed to make a strong attack satire on that era and try to make a difference in their works. Just as the beginning paragraph of Lady Chatterley's Lover. "Ours is essentially a tragic age, so we refuse to take it tragically. The cataclysm has happened, we are among the ruins, we start to build up new little habitats, to have new little hopes. It's rather hard work: there is now no smooth road into the future, but we go round, or scramble over the obstacles. We've got to live, no matter how many skies have fallen." (Lawrence, 2008, P.1)Where there is oppression, there is resistance. It's known that writers are the backbone of a country and a nation, and women's emancipation flows under the pen of writers such as Lawrence. Complaints were made against that era to defend feminism, and the women's liberation movement succeeded again and again in the successive works in terms of literature.

From the analysis of the detailed plot from Lady Chatterley's Lover, it is not difficult to figure out that the protagonist Connie appeared as an image of new woman who dared to fight against oppression from men and the present era. However, through further analysis of this work from the perspective of feminism theory, Connie didn't get rid of men, depending herself on another man, Mellors, yielding her body and happiness to him, lacking independence of herself, thus Connie cannot be counted as a "new woman". Regardless of this respect, she used to to condemn and break the bound of the convention, waiting for her own existence and happiness hopefully at the end of the story. As women in modern society, what we need to do is to pursue knowledge and freedom, strive for the value of self-realization, independence and happiness.

\section{REFERENCES}

[1] D.H. Lawrence. (2008). Lady Chatterley's Lover. Beijing: Foreign Language Press.

[2] Grand Sarah. (1894). The New Aspect of the Woman Question. North American Review. (March). 271.

[3] James Tompkins. (1987). Me and My Shadow. New Literary History, Vol. 19, No. 1, Feminist Directions (Autumn).169-178.

[4] Kate Millette. (1977). Sexual Politics. London: Virago Press. 
[5] Liu Cong. (2013). The intertexture between Female Liberation and Male Chauvinism: the Confliction between Narrative Voice and Character Voice in Lady Chatterley's Lover. Journal of Hezhou University. 29(01):52-56.

[6] Sigmund Fred. (1933). Introductory lectures on psychoanalysis. Harmondsworth: Penguin books.

[7] Simone de Beauvoir. (1972). The Second Sex. 1949. Reprint, Harmondsworth, England: Penguin.

[8] https://www.merriam-webster.com/dictionary/new woman. Retrived July 14, 2019.

Ting Wen was born in Yancheng, China in 1987. She will get postgraduate degree in the year of 2020 .

She is currently a postgraduate student in Grade 2 of English and American Literature Major, College of Foreign Studies, Nanjing Agricultural University, Nanjing, China. 